\title{
Ecologically relevant effects of pulse application of copper on the limpet Patella vulgata
}

\author{
Stephen R. Cartwright ${ }^{1,2, *}$, Ross A. Coleman ${ }^{1,3}$, Mark A. Browne ${ }^{1}$ \\ ${ }^{1}$ Marine Biology and Ecology Research Centre, University of Plymouth, Drake Circus, Plymouth PL4 8AA, UK \\ ${ }^{2}$ Present address: The Swire Institute of Marine Science, Department of Ecology \& Biodiversity, The University of Hong Kong, \\ Pokfulam Road, Hong Kong, SAR \\ ${ }^{3}$ Present address: Centre for Research on Ecological Impacts of Coastal Cities, Marine Ecology Laboratories (A11), \\ The University of Sydney, New South Wales 2006, Australia
}

\begin{abstract}
Along with habitat loss and climate change, anthropogenic inputs to the biosphere represent major threats to biodiversity; unfortunately, many of the studies necessary to understand these potential impacts have been carried out in laboratory systems with little or no ecological relevance. Understanding the impact of contaminants is dependent on the knowledge of their ecological consequences in the environment rather than reliance on laboratory studies. We assessed the impact of pulse contamination of copper on the behaviour and physiology of the limpet Patella vulgata L. on rocky shores. Toxicological methods were used in conjunction with ecological methods to elucidate possible effects of copper on cellular viability and phagocytosis (measures of cellular and immunological health), tenacity and grazing behaviour of $P$. vulgata. Exposures lasted for $10 \mathrm{~d}$, and were replicated on 2 shores, and at 2 times. Ecological effects were assessed by the deployment of wax discs to quantify grazing intensity of contaminated limpets during this period. We also tested the effects of copper on tenacity as a measure of vulnerability to predators or to wave action. Phagocytic activity was unaffected by the addition of copper, as was the grazing intensity of $P$. vulgata. Tenacity was significantly reduced due to the copper pulse exposure, as was cellular viability. Copper significantly affected cellular viability; this was also reduced, although to a lesser extent, in limpets sampled from control plaster block replicates, suggesting unidentified influences from the plaster itself. Copper levels were significantly elevated in limpets sampled from the copper treatment, suggesting this as a useful method of toxicant dosing in the field. Ecological effects were mixed. There was no change in grazing intensity, but a significant reduction in tenacity, with implications for limpet mortality and thus rocky shore ecosystem processes.
\end{abstract}

KEY WORDS: Copper $\cdot$ Plaster $\cdot$ Patella vulgata $\cdot$ Pulse disturbance $\cdot$ Grazing $\cdot$ Adhesion $\cdot$ Cellular viability $\cdot$ Phagocytic activity

\section{INTRODUCTION}

The major threats to biodiversity have been listed as habitat loss (Bascompte \& Rodriguez 2001), climate change (Parmesan \& Yohe 2003) and anthropogenic inputs (Laurance 2001). Anthropogenic activities resulting in metal contamination have been suggested as a global threat to biodiversity in coastal ecosystems (GESAMP 1994). Such disturbances from chemical inputs can potentially cause direct mortality to organ-

*Email: s.r.cartwright@gmail.com

All authors contributed equally to this work isms, and, as a result, indirectly alter the structure of intertidal assemblages (Southward \& Southward 1978). In order to determine the ecological effects of contaminants on resident organisms, it is necessary to identify how the organism is affected at different levels of biological organisation (Hebel et al. 1997). In coastal waters and estuaries world-wide, copper is a common contaminant (Johnston et al. 2002). Potential sources range from urban runoff, industry discharge, mining and metabolic wastes from agricultural animal hus- 
bandry, and as a component of anti-fouling paints used on boat hulls (Johnston \& Keough 2000, Johnston et al. 2002). Conventional laboratory studies have identified it as highly toxic and rate it as 1 of the 3 most toxic trace metals (Abel 1989).

Molluscan herbivores play a fundamental role in ecosystem processes, structuring intertidal assemblages by the removal of both microalgae and the propagules of macroalgae within the microalgal film (Hawkins et al. 1992). On exposed and moderately exposed rocky shores in the north-east Atlantic, limpets of the genus Patella are 'keystone' grazers (sensu Power et al. 1996). Across the western coasts of Europe, removal of limpets results in dominance by macroalgae, even though the magnitude of effects varied with location (Coleman et al. 2006). This pattern is consistent with observations from work in the southern hemisphere and on the north-west coast of the United States (Underwood 2000, Paine 2002).

Recently, Patella vulgata has been shown to be more sensitive to copper than routinely used monitoring species like Mytilus edulis L. and Carcinus maenas L., with significant effects on a range of biomarkers (lysosomal activity, metabolic impairment, heart rate, etc.) measured at $6.1 \mu \mathrm{g} \mathrm{Cu} \mathrm{l}{ }^{-1}$, whereas effects for the other 2 species were only apparent at $68.1 \mu \mathrm{g} \mathrm{Cu} \mathrm{l}^{-1}$ (Brown et al. 2004). Like most conventional laboratory studies (Calow 1994), however, this conclusion was drawn following continuous exposure at constant concentrations of the toxicants. This does not reflect the range of ecologically relevant factors present in the natural environment (Morrisey et al. 1996). Exposed on rocky shores, organisms would normally experience transient contamination events, through urban runoff or industrial spills, which would vary the timing and frequency of exposure to toxicants (Johnston \& Keough 2000). Therefore, in order to determine ecologically relevant effects of contamination on an organism, manipulative experiments in the field are necessary.

For limpets, a range of assays are available to determine toxicant effects at different levels of biological organisation, including cellular viability, phagocytosis (immunological), tenacity (neuromuscular function) and grazing intensity (foraging behaviour). Cellular viability (cell integrity and function) has been used to assess the sub-lethal effects of contaminant exposure to Mytilus edulis (Hagger et al. 2005) and Patella vulgata (Bloxham et al. 2004). The phagocytosis assay has been widely used to investigate effects of chemical toxicants on the immune systems of marine animals (Galloway \& Goven iin press), and exposure to copper has been shown to suppress the immune systems of the mussels M. edulis (Pipe et al. 1999) and Perna virdis (Nicholson 2003). Such contaminant-mediated reductions in immunological function may reduce survivor- ship by increasing the risk of infections from marine pathogens.

Tenacity in limpets is thought to provide protection against wave action and predation. Much work has focused on predators using physical force to detach limpets, for example oystercatchers (Coleman et al. 2004a) or crabs (Lowell 1986). Little is known, however, about how anthropogenic factors may affect the mechanisms that reduce successful attacks. Coleman et al. (2004a) suggested that variation in tenacity of Patella vulgata could have fitness consequences as a defence against predators. Should reduced health of the limpets impair their defensive capabilities, then those individuals would be more susceptible to predation. This could have knock-on effects on the composition of the shores, as there would be fewer grazers influencing the recruitment of algae.

As food supply is thought to be a major route of metal uptake (Depledge \& Rainbow 1990, Luoma 1990), we tested whether grazing intensity would be affected by the application of our treatments. Continued interest exists in the spatial and temporal patterns of the distribution and activity of intertidal gastropods (Hawkins \& Hartnoll 1983, Forrest et al. 2001, Jenkins et al. 2001, 2005, Coleman et al. 2004b), due to the direct and indirect consequences that grazing has on algal cover, as a fundamental component of the dynamics of rocky shore systems.

In order to test this, a toxicant dosing system previously used in soft sediments (Morrisey et al. 1996) was modified for use on the rocky shore habitat. Using the rocky shore as a tractable test system for experimental manipulation, point-source contamination was created in patches to elevate copper levels in Patella vulgata, in order to investigate whether the method is successful in delivering toxicant doses to a mobile grazer. This was achieved by deploying plaster blocks impregnated with copper on the shore amongst aggregations of limpets for $10 \mathrm{~d}$, with appropriate replicated controls.

The hypotheses tested were that the copper treatment would reduce the average health of limpets by: (1) reducing the average cellular viability and phagocytic activity of haemocytes, (2) reducing the average tenacity and (3) reducing the average grazing intensity.

\section{MATERIALS AND METHODS}

Experimental sites and timing. Experiments were carried out at 2 randomly chosen moderately exposed rocky shores in the south-west of the United Kingdom: Bovisand Bay $\left(50^{\circ} 20.26^{\prime} \mathrm{N}, 04^{\circ} 07.20^{\prime} \mathrm{W}\right)$ and Heybrook Bay $\left(50^{\circ} 19.13^{\prime} \mathrm{N}, 04^{\circ} 06.60^{\prime} \mathrm{W}\right)$; these locations 
were chosen as representative of the shores in the region. Areas of predominantly smooth flat rock, with few barnacles and no fucoids, and away from rock pools, which may restrict the movement of limpets grazing, were selected in the mid-shore. The toxicant dosing ran for $10 \mathrm{~d}$ before sampling and was initiated in mid-October and repeated in mid-November in new areas at least $10 \mathrm{~m}$ away from the first manipulation. Aggregations of Patella vulgata of at least 6 individuals were chosen as experimental units, where individual limpets were no further than $0.3 \mathrm{~m}$ away from an approximate central point. This allowed the removal of 3 individuals from each replicate group within a $0.3 \mathrm{~m}$ radius of the plaster blocks at the end of the experiment, allowing for losses due to predation, possible migration away from experimental plot area, and discarding of limpets where the tenacity jackets (see subsection 'Force measurement') failed. Ten replicates were set up for 3 treatments: plaster blocks impregnated with copper, control plaster blocks and controls (no plaster block).

Toxicant dosing. The toxicant dosing system designed by Morrisey et al. (1996) for soft sediments was modified for settlement plates to create localised concentrations of copper (Johnston \& Keough 2000). To create a point-source of pulse copper contamination on the rocky shore, a similar approach was used, deploying copper-impregnated plaster blocks onto the shore. To produce the blocks, $12.8 \mathrm{~g}$ of $\mathrm{CuSO}_{4}$ was completely dissolved in $52 \mathrm{ml}$ of Milli-Q-purified water and refrigerated at $4^{\circ} \mathrm{C}$ for $60 \mathrm{~min}$. Finishing plaster (Wickes) was weighed out $(60 \mathrm{~g})$ and refrigerated for $60 \mathrm{~min}$, before being mixed with the copper solution. The mixture was poured and set into cylindrical plastic moulds (6 $\mathrm{cm}$ in diameter and $6 \mathrm{~cm}$ in height) and left to set at room temperature for $3 \mathrm{~d}$ before use. Control blocks were created using the same method, without the addition of $\mathrm{CuSO}_{4}$. Control plots were unmanipulated. Preliminary trials had shown that plaster dissolution rates were not apparently different between sites and shores and that the maximal survival time of the blocks was approximately $6 \mathrm{~d}$. The longevity of the blocks enabled us to run a short-pulse copper-exposure experiment for the duration of $10 \mathrm{~d}$, which is comparable with laboratory studies (Brown et al. 2004) and field studies (Johnston et al. 2002, 2003).

Plaster blocks were attached to the shore by drilling 4 holes $(3 \mathrm{~cm}$ deep) in a $0.12 \mathrm{~m} \times 0.12 \mathrm{~m}$ square; rawl plugs were then fitted into each of the holes, and the block was centred in the middle. A netted nylon bag was wrapped around the block, and the corners of the bag were pinned down tightly using galvanised screws in the holes. This effectively minimised movement by the blocks, which would cause mechanical damage to the blocks by grating on the rock surface. It also pre- vented large fragments of the block from breaking off through attrition and washing away. These blocks were placed adjacent to the limpet aggregations. The limpets did not exhibit any avoidance behaviour with respect to the blocks; for the duration of the exposure, limpets were always found at low tide, within a 5 to $20 \mathrm{~cm}$ radius, if not under the netting. Blocks were replaced on Day 5 of each experiment to ensure the presence of treatment blocks until the end of the $10 \mathrm{~d}$ exposure period. Tenacity was recorded on site, and haemolymph was collected from individual limpets (limpets randomly chosen near a treatment block) using 21.5 gauge needles and $1 \mathrm{ml}$ syringes in the laboratory. These limpets were kept frozen at $-80^{\circ} \mathrm{C}$ prior to chemical analyses.

Copper analysis. Three limpets from each treatment were freeze dried in a desiccator (Edwards Super Modulyo) prior to analysis. Three limpets were necessary to achieve sufficient mass of flesh for accurate detection. The dried mass was removed from the shells, and the mass of the 3 limpets from each replicate plot was recorded. This was then treated with $20 \mathrm{ml}$ of nitric acid $(0.69 \mathrm{M})$ and boiled gently on a hot plate for 6 to $7 \mathrm{~h}$ until all solid matter had been digested. The clear solution was then left to cool and topped up with Milli-Q-purified water to $25 \mathrm{ml}$ in a volumetric flask. The samples were analysed using flame atomic absorption spectrometry (GBC Scientific Equipment) at a wavelength of $324.7 \mathrm{~nm}$, a lamp current of $5 \mathrm{~mA}$ and a slit width of $0.5 \mathrm{~nm}$; the flame type used was an air/ethyne flow, 9 and $31 \mathrm{~min}^{-1}$, respectively. Body burdens of copper were then calculated using the absorbance multiplied by the volume, divided by the mass of the limpets to give a concentration $\left(\mu \mathrm{g} \mathrm{Cu} \mathrm{g}^{-1}\right.$ dry tissue mass). Differences were assessed using an ANOVA run on WinGMAv 5 (EICC, The University of Sydney), with homogeneity of variances checked prior to analysis using Cochran's test (Underwood 1997); analysis of significant interactions was determined using post hoc SNK (Student-Newman-Keuls) tests.

Cellular viability and phagocytosis. The cellular viability assay utilised a modification of previous methods (Coles et al. 1995, Pipe et al. 1999). A $50 \mu \mathrm{l}$ aliquot of haemolymph was pipetted into duplicate wells of microtitre plates and agitated using a plate shaker (1400 rpm for $60 \mathrm{~s}$ ). The plate was then left for $50 \mathrm{~min}$ to allow cells to adhere at the bottom of the wells. After the incubation period, excess cells were discarded, and the plates were washed with phosphate buffer solution. Neutral red dye $(0.4 \%)$ was then added, and cells were incubated in the dark for $3 \mathrm{~h}$ to prevent photolysis. Wells were then washed with phosphate buffer solution again before an acidified solution of $1 \%$ acetic acid $/ 20 \%$ ethanol was added to resolubilise the dye (Galloway et al. 2004). Absorbance was read at $550 \mathrm{~nm}$ 
using a spectrophotometer. The total protein in the haemolymph was determined following the method of Bradford (1976), and results were presented as optical density per gram protein. Differences were assessed using ANOVA.

The phagocytosis assay was again a modification of previous methods (Coles et al. 1995, Pipe et al. 1999). A $50 \mu \mathrm{l}$ sample of haemocytes was transferred in duplicate into a microtitre plate and agitated using a plate shaker (1400 rpm for $60 \mathrm{~s}$ ). The plate was covered with a plate-sealer and incubated at $10^{\circ} \mathrm{C}$ for $50 \mathrm{~min}$. Aliquots of $50 \mu \mathrm{l}$ of neutral-red-stained and heat-stabilised zymosan suspension (containing $1 \times 10^{5}$ particles $\mathrm{ml}^{-1}$ in phosphate buffer) were added to each well, and the plate was incubated for $3 \mathrm{~h}$ at $10^{\circ} \mathrm{C}$. The cells were washed to remove residual haemocytes using $100 \mu$ phosphate buffer ( $\mathrm{pH}$ 7.4), and a series of zymosan standards were added. The dye was resolubilised via addition of $100 \mu \mathrm{l}$ of acetic acid in $50 \%$ ethanol. The microtitre plate was covered with a platesealer and incubated for $10 \mathrm{~min}$ at $20^{\circ} \mathrm{C}$, and then read at $550 \mathrm{~nm}$. The total protein in the haemolymph was determined (Bradford 1976), and results were presented as the number of zymosan particles phagocytosed per gram coelomocyte protein. Differences in phagocytic activity were tested using ANOVA as above.

Force measurement. This was as in Coleman et al. (2004a). Attachment shells, choosing the best fitting ones, were glued onto the limpets using silicone sealant glue, allowing $24 \mathrm{~h}$ for the glue to harden and for the limpet to re-adjust from the disturbance caused by the method. Previous work had shown no artefacts from the glue curing. On Day 10 of the experiment, the force $(\mathrm{kg})$ required to detach the limpet from the substrate was measured using a digital spring scale (Kern CH50, Kern and Sohn). Any data where the test limpet pulled away substratum or the attachment point failed were discarded. As the strength of attachment to the substratum is proportional to the surface area of the foot (Grenon \& Walker 1981), the detachment force (kg) was converted to Newtons and divided by the surface area of the foot, measured as the maximum length and maximum width of the shell. This gave tenacity per foot area. An individual limpet was randomly selected for measurement $\left(n=10\right.$ treatment $\left.^{-1}\right)$. Differences in average tenacity between treatments, shores and dates were examined by ANOVA.

Quantifying grazing. Grazing activity was assessed by using an array of wax discs embedded into the rock surface (Thompson et al. 1997) to record the graze marks caused by radula, which could be identified using a binocular microscope. Wax discs were deployed in a $3 \times 3$ array, in a $0.2 \times 0.2 \mathrm{~m}$ area, which was $\sim 0.1 \mathrm{~m}$ away from the treatment block or, for control plots, from the approximate central point of the limpet aggregation. The percentage of the surface area scraped was determined using a pointintercept method (Jenkins et al. 2001). An eyepiece graticule with 25 dots spaced over a circular area the size of a wax disc was placed over the disc being observed. Under a microscope, total points intercepting grazing marks were then multiplied by 4 , to give the percentage cover of the disc. The average value of the discs collected from each array was then calculated to give an estimate of grazing activity of each experimental plot. This was used as a replicate measure in an ANOVA.

\section{RESULTS}

\section{Copper analysis}

There was a significant interaction between location and treatment (Table 1). Overall, limpets at Bovisand

Table 1. Comparison using 3-factor ANOVA to investigate variations for 2 locations (Lo: Bovisand and Heybrook), considered as random, 2 times (Ti: mid-October and mid-November) and 3 treatments (Tr: control, control block, copper block), both factors considered fixed. Data were $\operatorname{sqrt}(x+1)$ [copper body burdens] or $\ln (x+1)$ [tenacity] transformed when necessary to homogenise variances. Significant differences are shown in bold $;-$ : these factors were eliminated from the analysis to increase the power of tests for effects of interest as $p>0.25$ (Underwood 1997)

\begin{tabular}{|c|c|c|c|c|c|c|c|c|c|c|c|c|c|c|c|c|}
\hline \multirow[t]{2}{*}{ Source } & \multirow[t]{2}{*}{ df } & \multicolumn{3}{|c|}{$\begin{array}{l}\text { Copper body } \\
\text { burdens }\end{array}$} & \multicolumn{3}{|c|}{$\begin{array}{l}\text { Cellular } \\
\text { viability }\end{array}$} & \multicolumn{3}{|c|}{$\begin{array}{c}\text { Phagocytic } \\
\text { activity }\end{array}$} & \multicolumn{3}{|c|}{ Tenacity } & \multicolumn{3}{|c|}{ Grazing } \\
\hline & & MS & $F$ & $\mathrm{p}$ & MS & $F$ & $\mathrm{p}$ & MS & $F$ & $\mathrm{p}$ & MS & $F$ & $\mathrm{p}$ & MS & $F$ & $\mathrm{p}$ \\
\hline Lo & 1 & 7.93 & 7.93 & $<0.001$ & 0.5977 & 1.29 & $>0.4$ & 117.32 & 4.04 & $<0.05$ & 0.3 & 0.28 & $>0.6$ & 7.84 & 0.2 & $>0.6$ \\
\hline $\mathrm{Ti}$ & 1 & 0.15 & 0.15 & $>0.6$ & 9.362 & 20.19 & $>0.1$ & 71.76 & 2.74 & $>0.3$ & 0.05 & 0.05 & $>0.8$ & 2.38 & 0.5 & $>0.6$ \\
\hline $\operatorname{Tr}$ & 2 & 30.59 & 30.59 & $<0.05$ & 6.4611 & 12.15 & $<0.001$ & 257.2 & 1.43 & $>0.4$ & 3.22 & 32.77 & $<0.05$ & 19.01 & 0.19 & $>0.8$ \\
\hline $\mathrm{Lo} \times \mathrm{Ti}$ & 1 & 0.45 & 0.45 & $>0.2$ & 0.4637 & 0.87 & $>0.3$ & 26.23 & 0.9 & $>0.3$ & 1.08 & 6.07 & $<0.05$ & 4.75 & 0.12 & $>0.7$ \\
\hline Lo $\times \operatorname{Tr}$ & 2 & 1.55 & 1.55 & $<0.05$ & 0.0613 & & & 180.22 & 6.2 & $<0.01$ & 0.2 & - & & 101.98 & 2.6 & $>0.07$ \\
\hline $\mathrm{Ti} \times \operatorname{Tr}$ & 2 & 0.01 & 0.01 & $>0.9$ & 0.5629 & & & 169.12 & 3.8 & $>0.2$ & 0.2 & - & & 8.97 & 0.13 & $>0.8$ \\
\hline Lo $\times \operatorname{Ti} \times \operatorname{Tr}$ & 2 & 0.24 & 0.24 & $>0.4$ & 0.0762 & & & 44.49 & 1.53 & $>0.2$ & 0.1 & 0.55 & $>0.5$ & 69.57 & 1.77 & $>0.1$ \\
\hline Residual & 108 & 0.33 & 0.33 & & 0.5318 & & & 29.06 & & & & & & & & \\
\hline
\end{tabular}


Bay (mean value \pm SE) had lower levels of copper than limpets Patella vulgata at Heybrook Bay (Fig. 1). The interaction was not one of direction, but of magnitude, so effects were consistent across locations. With regards to treatment, there was a consistent pattern of copper uptake for both location and times. The impregnated plaster blocks significantly elevated the body burdens of copper in limpets (Fig. 1, Table 1).

\section{Cellular viability}

There was a clear effect in cellular viability across treatments (Table 1, Fig. 2): control > control plaster block > copper plaster block. The presence of copper and plaster significantly reduced the viability of haemocytes within Patella vulgata compared to each other and the unmanipulated treatment.

\section{Phagocytosis}

There was significant interaction between location and treatment (Table 1). At Bovisand Bay, there was a significant difference between the treatments containing plaster and the un-manipulated control treatment. At Heybrook Bay, limpets from all 3 treatments did not differ in terms of phagocytic function (Fig. 3).

\section{Tenacity}

Limpets in copper block treatments showed a reduction in tenacity (Table 1, Fig. 4). There was also,

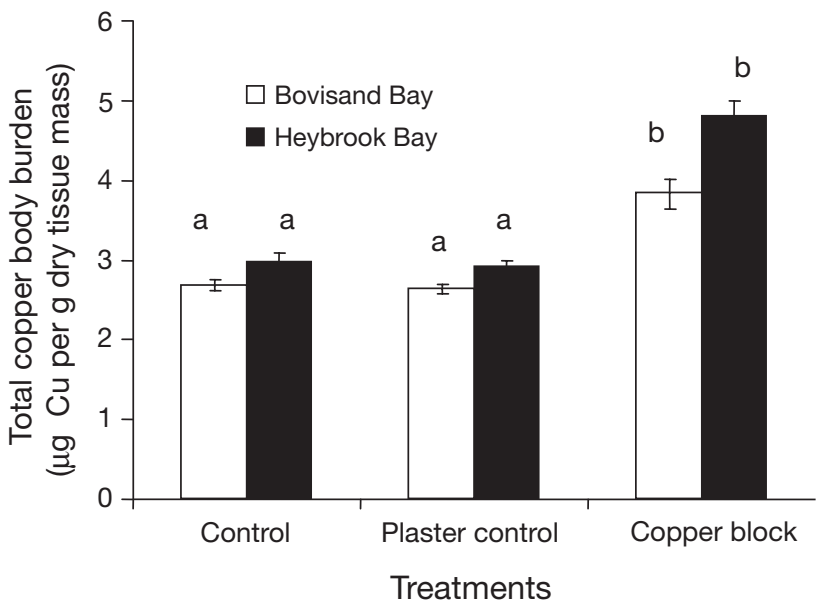

Fig. 1. Patella vulgata. Concentration of copper accumulated in the limpets for 3 treatments at 2 locations. Error bars: \pm SEM. The same letters above bars indicate no significant difference by post hoc SNK (Student-Newman-Keuls) tests

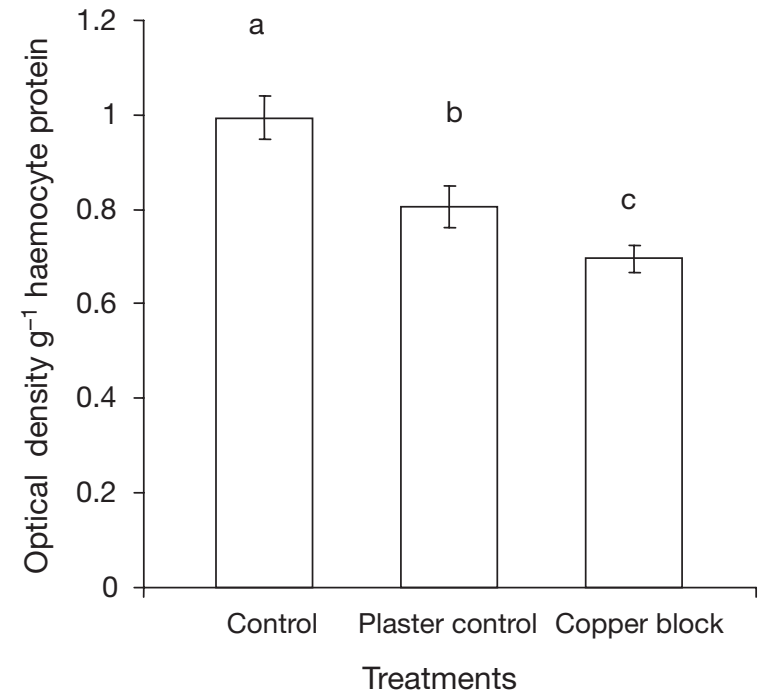

Fig. 2. Patella vulgata. Individual health of limpets measured by cellular viability as the optical density per gram of haemocyte protein for the 3 treatments. Error bars: \pm SEM. The same letters above bars indicate no significant difference by post hoc SNK (Student-Newman-Keuls) tests

however, significant interaction between location and time (Table 1), with limpets at Bovisand Bay having significantly higher tenacity at Sampling Time 1 than at Time 2, conversely at Heybrook Bay, limpets had higher tenacity values at Sampling Time 2 compared to Time 1 (Fig. 5).

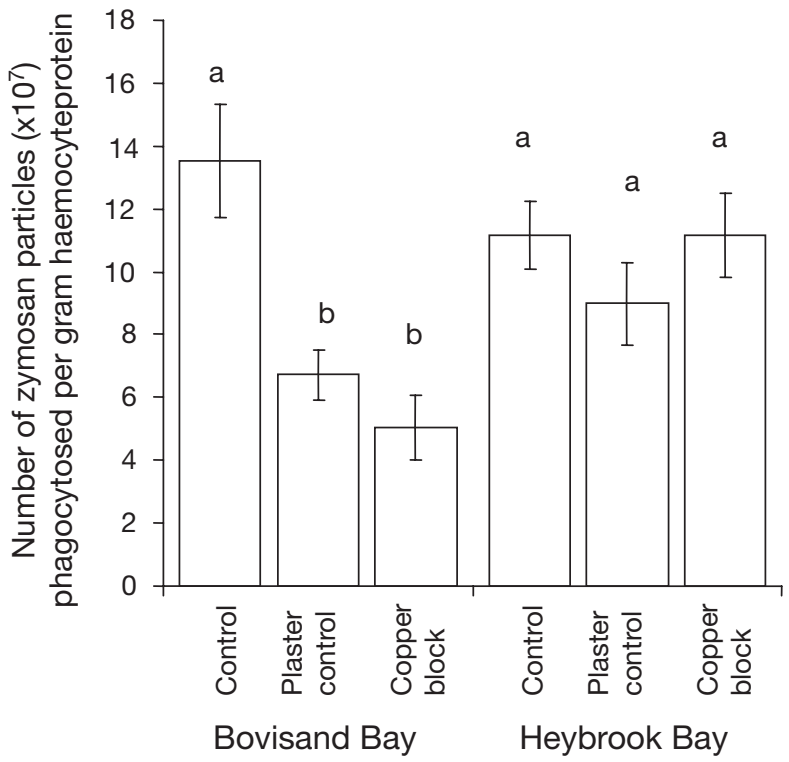

Fig. 3. Patella vulgata. Phagocytic activity of limpets in relation to applications of copper. Number of zymosan particles phagocytosed per gram of haemocyte protein for 3 treatments at 2 locations. Error bars: \pm SEM. The same letters above bars indicate no significant difference by post hoc SNK (StudentNewman-Keuls) tests 


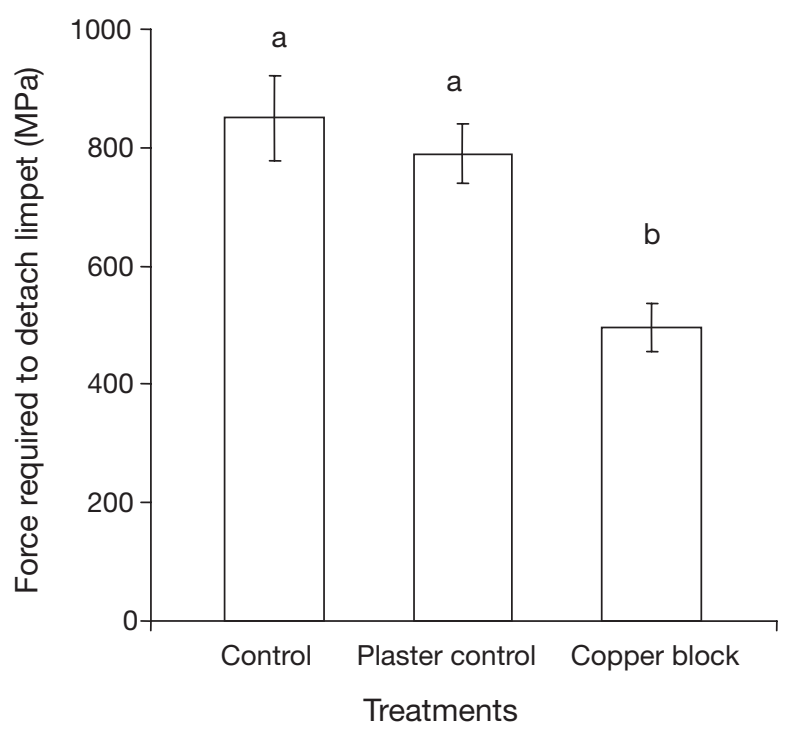

Fig. 4. Patella vulgata. Average tenacity of limpets for 3 treatments. Error bars: \pm SEM. The same letters above bars indicate no significant difference by post hoc SNK (StudentNewman-Keuls) tests

\section{Grazing}

No significant difference was found (Table 1) in grazing activity, with respect to the addition of copper (Fig. 6), at either site.

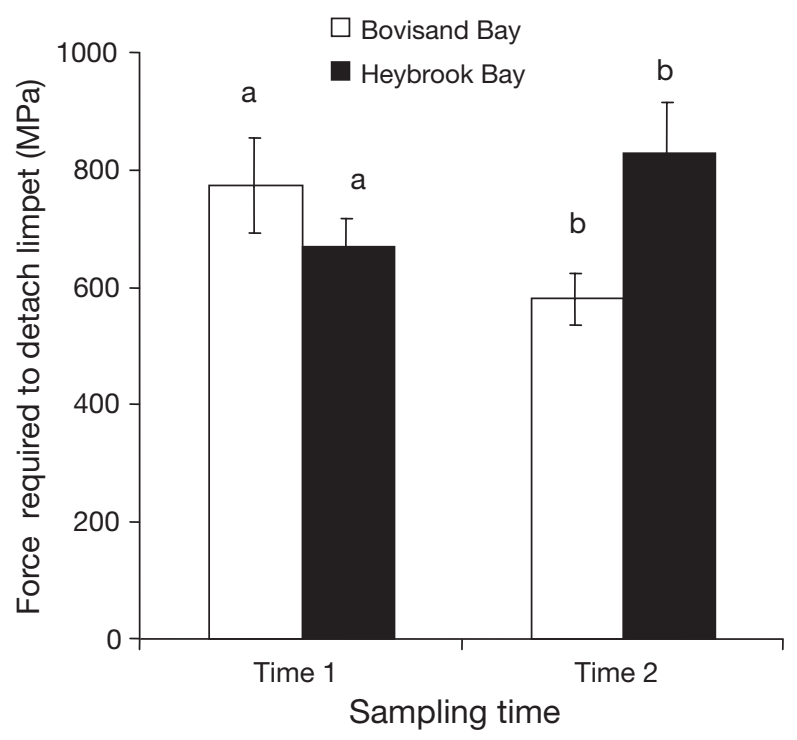

Fig. 5. Patella vulgata. Average tenacity of limpets for 2 sampling times at both locations. Error bars: \pm SEM. The same letters above bars indicate no significant difference by post hoc SNK (Student-Newman-Keuls) tests

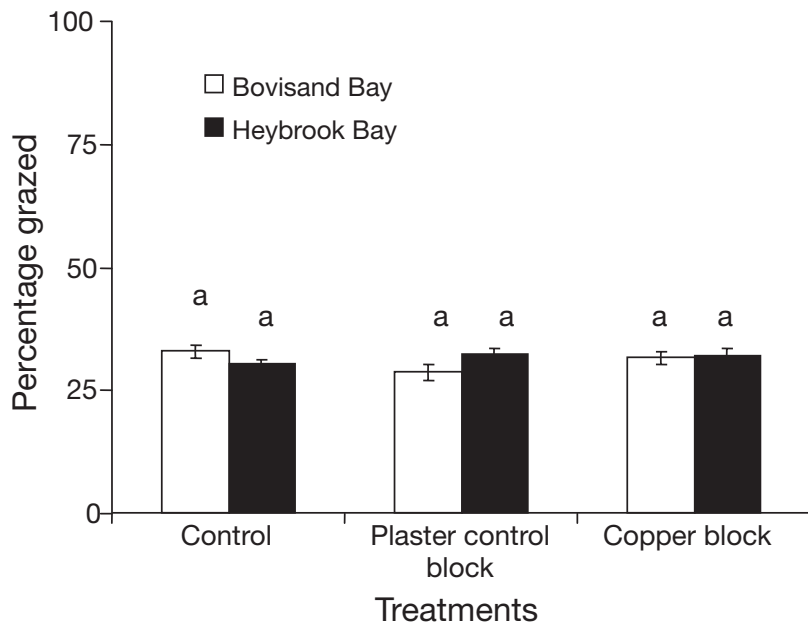

Fig. 6. Patella vulgata. Differences in grazing intensity. Mean percentage grazing intensity for 3 treatments at both locations. Error bars: \pm SEM. The same letters above bars indicate no significant difference by post hoc SNK (Student-NewmanKeuls) tests

\section{DISCUSSION}

The toxicant dosing system was successful in elevating copper concentrations in limpets Patella vulgata close to the copper blocks as compared to control limpets. On wave-swept rocky shores, limpets may be subjected to water velocities in excess of $20 \mathrm{~m} \mathrm{~s}^{-1}$ (Denny 2000), creating a dynamic environment in which contaminants would not be permanently isolated to specific areas. As such, it is considered that limpets up to $0.15 \mathrm{~m}$ away from the copper block would not be exposed to very high concentrations of copper, as it would be dissipated by waves and diluted as the distance from the point of discharge increases (Bishop et al. 2002). The main routes of copper uptake for limpets in the present study were likely to be through the gills or from grazing of material containing copper ions bound to the substratum or in the epilithic biofilm. Work has been done in soft-sediment systems using plaster blocks to deliver metals other than copper, as well as a combination of metals (Lindegarth \& Underwood 1999). Our results support this method as a versatile means to deliver measured toxicants in the field, to possibly gain a more realistic assessment of ecological impacts on rocky shore organisms than possible through laboratory experiments. Given that in many other rocky shore systems grazing molluscs do not home, it is highly likely that many more blocks would have to be used in a single treatment replicate to achieve the same level of contaminant (Lindegarth \& Underwood 1999) over the movement range of the organisms concerned. 
The significant effects of the copper treatments were manifested as reductions in the viability of haemocytes and in the adhesive capacity of Patella vulgata. Reductions in haemocellular viability may occur simultaneously with reductions in tenacity. Tenacity is likely to be a crucial defence against predation, wave action and physical impacts from water-borne objects (Shanks \& Wright 1986). Any reductions in tenacity are, therefore, likely to have direct consequences on the survivorship potential of $P$. vulgata. There were also significant effects from the plaster control blocks in relation to cellular viability, which is consistent with medical evidence after exposure to plaster which suggests that the lime (calcium oxide) used in plaster can cause cellular and tissue damage in humans (Winder \& Carmody 2002). Continual breakdown of the plaster blocks could also lead to increased particulate matter in the immediate surroundings of the limpets, possibly resulting in irritation or damage of the gill epithelial tissue.

Phagocytosis showed a location versus treatment interaction, whereas grazing activity was unaffected by the treatments. For phagocytosis, the predicted immunosuppressive trend was present at Bovisand Bay, but not at Heybrook Bay, suggesting that such toxicological studies dealing with sub-lethal responses need to take into account spatial patterns of variability when assessing the impact of toxicants on marine organisms. As the experiments were only run for $10 \mathrm{~d}$, identification of transient, sub-lethal effects was not possible (Johnston \& Keough 2000). The duration of this experiment may, therefore, have been too short for effects to manifest themselves. The fact that limpets continued to forage, with no apparent reduction in grazing, suggests that Patella vulgata does not exhibit any immediate avoidance behaviour due to copper input in the short term. If the duration were longer, the reduction in the limpet's health might have continued to decrease as a result of longer exposure, and it is possible that, with increased duration, effects on foraging may become evident. Although there was no change in grazing behaviour, this same experimental approach could be utilised to deliver contaminants in order to investigate other parameters, such as cardiac activity (De Pirro et al. 2001, Brown et al. 2004, Chelazzi et al. 2004), or to put a greater focus on individual parameters, such as grazing, but over a longer time scale. Delayed effects, such as reduced grazing or competitive ability, could influence the time to reach reproductive maturity or fecundity, which would have longterm consequences for rocky shore dynamics.

This study demonstrates a significant reduction in Patella vulgata's ability to adhere to the substratum when exposed to a $10 \mathrm{~d}$ copper pulse; it would be interesting to determine what would happen in a multiple pulse experiment in which limpets are exposed several times to short treatments, or even a press application, i.e. continuous exposure over a substantial period of time. If a minimum attachment strength limit is reached or exceeded, we would expect increased mortality due to dislodgement or greater predation rates. Here, there is a simple sub-lethal ecological impact of copper contamination. The defence of limpets against attack by birds (Coleman et al. 2004a) and crabs (Lowell 1986) is to clamp down. So even with a single-pulse event, there is potential for food webs to be disrupted. Coleman et al. (1999) noted a low success rate of oystercatchers foraging on limpets; this was due to clamping in response to a predator-derived stimulus. Thus, copper contamination has the potential to increase predator success and so directly impact ecosystem processes such as herbivory. The consequences of such processes for assemblage composition (Wootton 1992, Coleman et al. 2006) may be independent of the effect of copper on the grazing behaviour of the limpets. So, in considering the sublethal effects of contaminants on significant organisms in ecosystem, indirect interactions must also be assessed.

Acknowledgements. This research was funded by the Nuffield Foundation through an Undergraduate Research Bursary (URB/001808/B) to S.R.C and R.A.C. Thanks to D. Stone, J. Hill, M. Dibley and P. Moore for field assistance, A. Fisher for help with the flame atomic absorbance spectrometer. S.R.C. thanks Dr. G. Williams and his group for comments on the manuscript. The authors also thank Dr. T. Galloway and her group for laboratory support. This paper was substantially improved by thoughtful comments by 3 anonymous referees.

\section{LITERATURE CITED}

Abel PD (1989) Water pollution biology. Ellis Horwood, Chichester

Bascompte J, Rodriguez MA (2001) Habitat patchiness and plant species richness. Ecol Lett 4:417-420

Bishop MJ, Underwood AJ, Archambault P (2002) Sewage and environmental impacts on rocky shores: necessity of identifying relevant spatial scales. Mar Ecol Prog Ser 236: 121-128

Bloxham $M$, Jones $M$, Galloway $T$, Lowe $D$, Browne $M$, Depledge M (2004) Ecosystem management bioindicators-Final report. University of Plymouth and Plymouth Marine Laboratory

Bradford MM (1976) Rapid and sensitive method for quantification of microgram quantities of protein utilising principle of protein-dye binding. Anal Biochem 72(1-2): 248-254

Brown RJ, Lowe D, Browne MA, Dissanayake A, Jones M, Galloway T, Depledge MH (2004) Differential sensitivity of three invertebrate species to copper assessed using biomarkers of exposure and effect. Aquat Toxicol 66(3): $267-278$

Calow P (ed) (1994) Handbook of ecotoxicology, Vol 2. Blackwell Scientific Publications, Oxford

Chelazzi G, De Pirro M, Williams GA (2004) Different cardiac responses to copper in limpets from metal polluted and clean shores of Hong Kong. Mar Environ Res 58:83-93 
Coleman RA, Goss-Custard JD, Le V, Dit Durell SEA, Hawkins SJ (1999) Limpet Patella spp. consumption by oystercatchers Haematopus ostralegus: a preference for solitary prey items. Mar Ecol Prog Ser 183:253-261

Coleman RA, Browne MA, Theobalds T (2004a) Prey aggregation functioning as a group defense via vibration-vigilance: limpet tenacity changes in response to simulated predator attack. Ecology 85(4):1153-1159

Coleman RA, Underwood AJ, Chapman MG (2004b) Absence of costs of foraging excursions in relation to limpet aggregation. J Anim Ecol 73:577-584

Coleman RA, Underwood AJ, Benedetti-Cecchi L, Åberg P and 8 others (2006) A continental scale evaluation of limpet grazing on rocky shores. Oecologia 147(3):556-564

Coles JA, Farsley SR, Pipe RK (1995) Alteration of the immune response of the common marine mussel Mytilus edulis resulting from exposure to cadmium. Dis Aquat Org 22(1): 59-65

Denny MW (2000) Limits to optimization: fluid dynamics, adhesive strength and the evolution of shape in limpet shells. J Exp Biol 203:2589-2601

De Pirro M, Chelazzi G, Borghini F, Focardi S (2001) Variations in cardiac activity following acute exposure to copper in three co-occurring but differently zoned Mediterranean limpets. Mar Pollut Bull 42(12):1390-1396

Depledge $\mathrm{MH}$, Rainbow PS (1990) Models of regulation and accumulation of trace-metals in marine-invertebrates. Comp Biochem Physiol C 97:1-7

Forrest RE, Chapman MG, Underwood AJ (2001) Quantification of radular marks as a method for estimating grazing of intertidal gastropods on rocky shores. J Exp Mar Biol Ecol 258:155-171

Galloway TS, Goven A (in press) Immunotoxicology in wildlife species: invertebrates. In: Luebke $\mathrm{R}$, House $\mathrm{R}$ (eds) Immunotoxicology and immunopharmacology, 3rd edn. Taylor and Francis

Galloway TS, Brown RJ, Browne MA, Dissanayake A, Lowe D, Jones MB, Depledge MH (2004) Rapid assessment of marine pollution in Southampton water, UK: a multi-biomarker approach to ecosystem management. Environ Sci Technol 38(6):1723-1731

GESAMP (Group of Experts on the Scientific Aspects of Marine Pollution) (1994) Biological indicators and their use in the measurement of the condition of the marine environment. GESAMP Rep Stud 55:1-56

Grenon JF, Walker G (1981) The tenacity of the limpet Patella vulgata L.: an experimental approach. J Exp Mar Biol Ecol 54:277-308

Hagger JA, Depledge MH, Galloway TS (2005) Toxicity of tributyltin in the marine mollusc Mytilus edulis. Mar Pollut Bull 51:811-816

Hawkins SJ, Hartnoll RG (1983) Grazing of intertidal algae by marine invertebrates. Oceanogr Mar Biol Annu Rev 21: 195-282

Hawkins SJ, Hartnoll RG, Kain JM, Norton TA (1992) Plant-animal interactions on hard substrata in the northeast Atlantic. In: John DM, Hawkins SJ, Price JH (eds) Plant-animal interactions in the marine benthos, Systematics Association Spec Vol 46. Clarendon Press, Oxford, p 1-32

Hebel D, Jones MB, Depledge MH (1997) Responses of crustaceans to contaminant exposure: a holistic approach Estuar Coast Shelf Sci 44:117-184

Jenkins SR, Arenas F, Arrontes J, Bussell J and 10 others (2001) European-scale analysis of seasonal variability in limpet grazing activity and microalgal abundance. Mar Ecol Prog Ser 211:193-203

Editorial responsibility: Roger Hughes (Contributing Editor), Bangor, UK
Jenkins SR, Coleman RA, Della-Santina P, Hawkins SJ, Burrows MT, Hartnoll RG (2005) Regional scale differences in the determinism of grazing effects in the rocky intertidal. Mar Ecol Prog Ser 287:77-86

Johnston EL, Keough MJ (2000) Field assessment of effects of timing and frequency of copper pulses on settlement of sessile marine invertebrates. Mar Biol 137:1017-1029

Johnston EL, Keough MJ, Qian PY (2002) Maintenance of species dominance through pulse disturbances to a sessile marine invertebrate assemblage in Port Shelter, Hong Kong. Mar Ecol Prog Ser 226:103-114

Johnston EL, Webb AJ, Keough MJ (2003) Pulse disturbances to the colonisation of hard-substrates and in situ determination of copper using diffusive gradients in thin-films (DGT): quantifying dose and response in the field. Biofouling 19(5):335-345

Laurance WF (2001) Future shock: forecasting a grim fate for the Earth. Trends Ecol Evol 16:531-533

Lindegarth M, Underwood AJ (1999) Technical note: using an experimental manipulation of contaminants in intertidal sediments. Ecotoxicology 8:495-501

Lowell RB (1986) Crab predation on limpets: predator behaviour and defensive features of the shell morphology of the prey. Biol Bull (Woods Hole) 171:759-762

Luoma SN (1990) Processes affecting metal concentrations in estuarine and coastal marine sediments. In: Furness RW, Rainbow PS (eds) Heavy metals in the marine environment. CRC Press, Boca Raton, p 51-66

Morrisey DJ, Underwood AJ, Howitt L (1996) Effects of copper on the faunas of marine soft-sediments: an experimental field study. Mar Biol 125:199-213

Nicholson S (2003) Lysosomal membrane stability, phagocytosis and tolerance to emersion in the mussel Perna viridis (Bivalvia: Mytilidae) following exposure to acute, sublethal, copper. Chemosphere 52:1147-1151

Paine RT (2002) Trophic control of production in a rocky intertidal community. Science 296:736-739

Parmesan C, Yohe G (2003) A globally coherent fingerprint of climate change impacts across natural systems. Nature 421:37-42

Pipe RK, Coles JA, Carissan FMM, Ramanathan K (1999) Copper induced immunomodulation in the marine mussel, Mytilus edulis. Aquat Toxicol 46:43-54

Power ME, Tilman D, Estes JA, Menge BA and 6 others (1996) Challenges in the quest for keystones. Bioscience 48: 609-620

Shanks AL, Wright WG (1986) Adding teeth to wave action: the destructive effects of wave-borne rocks on intertidal organisms. Oecologia 69:420-428

Southward AJ, Southward EC (1978) Re-colonisation of rocky shores in Cornwall after use of toxic dispersants to clean up Torrey Canyon oil spill. J Fish Res Board Can 35:682-706

Thompson RC, Johnson L, Hawkins SJ (1997) A method for spatial and temporal assessment of gastropod grazing intensity in the field: the use of radula scrapes on wax discs. J Exp Mar Biol Ecol 218:63-76

Underwood AJ (1997) Experiments in ecology: their logical design and interpretation using analysis of variance. Cambridge Unversity Press

Underwood AJ (2000) Experimental ecology of rocky intertidal habitats: What are we learning? J Exp Mar Biol Ecol 250:51-76

Winder C, Carmody M (2002) The dermal toxicity of cement. Toxicol Ind Health 18:321-331

Wootton (1992) Indirect effects, prey susceptibility, and habitat selection: impact of birds on limpets and algae. Ecology 73:981-991

Submitted: January 31, 2006; Accepted: March 27, 2006

Proofs received from author(s): October 10, 2006 